\title{
Analysis of Website Utilization for Online Motor Vehicle Insurance Purchases
}

\author{
Fia Fridayanti Adam ${ }^{1 *}$, Yulial Hikmah ${ }^{2}$ \\ ${ }^{1,2}$ Insurance and Actuarial Department, Vocational Education Program, \\ Universitas Indonesia \\ *Email: fia@ vokasi.ui.ac.id
}

\begin{abstract}
Motor vehicle insurance is the best known general insurance business line. Usually, insurance companies receive customers through insurance agents, but there are times when customers are less comfortable when dealing with insurance agents. Hence, insurance companies can take advantage of their official websites as platforms for selling insurance products.

Of the 74 current general insurance companies registered in Indonesia, only 61 companies can be accessed from its website. Furthermore, of the 53 companies that sell motor vehicle insurance products, only nine general insurance companies provide online applications. This indicates sub-optimal utilization of the companies' websites. It was also found that the nine websites that have online applications have a low customer uptake, with the number of unique visitors per day ranging from 5 to 1,250 .
\end{abstract}

Keywords: motor vehicle insurance, official website

\section{Introduction}

In general, there are two types of the insurance: life insurance and general insurance. According to Law No. 40 of 2014 concerning Insurance Business, life insurance is a business that carries out risk mitigation services and provides payment to policyholders, insured, or other parties who are entitled in the event of the insured dies or survives, or other payments to the policyholder, the insured, or any other party entitled at a specified time stipulated in the agreement, of which the amount has been determined and/or based on the results of the fund management. The general insurance business is a risk-based service that provides reimbursement to the insured or policyholder for any loss, damage, expenses incurred, loss of profits, or legal liability to any third party.

Motor vehicle insurance is the best known general insurance product and policy numbers increase accordingly with vehicle ownership in Indonesia as shown in Figure 1.

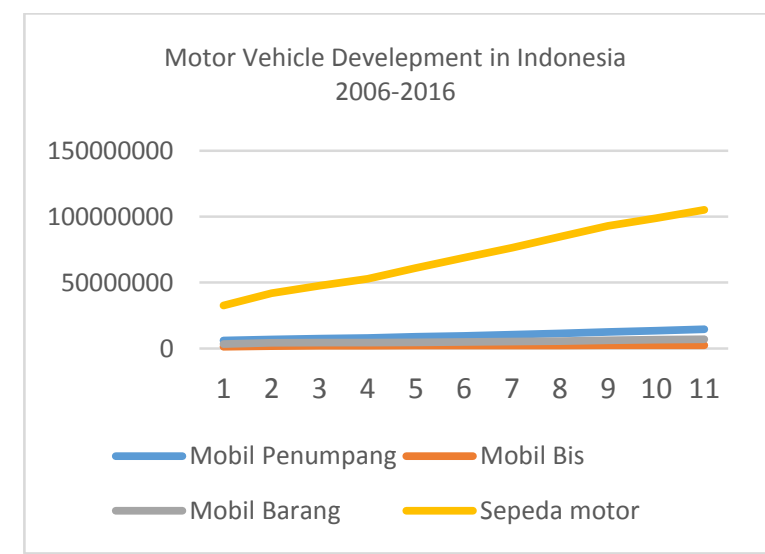

Source: https://www.bps.go.id/linkTableDinamis/view/id/1133

Figure 1 Motor vehicle Ownership in Indonesia (2006-2016)

Increases in the number of motor vehicles cause an increase in the level of risk through loss, damage, and others. Thus, the need for motor vehicle insurance to manage the risk also increases.

Usually, insurance companies receive their customers through an insurance agent. Insurance agents can be considered the "spearhead" of insurance marketing. Insurance agents represent the insurance company when deciding on the sale of insurance to prospective customers: they know, serve, and dominate the customer 
portfolio. Similarly, insurance agents also market vehicle insurance products. They should be able to explain the definition of motor vehicle insurance, the type of motor vehicle insurance coverage, how the benefits will be received, and other information. However, there are times when customers are less comfortable when dealing with insurance agents. According to Stroe (2014) customers will buy insurance because they feel confident and secure about the products offered. For that reason, insurance companies have to think of other ways to increase the number of customers. One way use is to utilize information technology.

Rapid technological developments have caused many changes, especially in the field of information technology. The ability of information technology to solve various problems in all fields is also increasing. Various innovations in information technology can help solve various technical problems in human life. Information technology is also expected to be able to bring innovations in various sectors, including the insurance sector. Klapkiv and Klapkiv (2017) stated that the main factors that determine the emergence of new technology in the field of insurance is information asymmetry, increasing competition, changes in generational and social norms, growth in technical and computer skills, economic crises, and decreased insurance premiums. Companies in the insurance, banking, and tourism sectors are keen to market their products through their corporate websites (Deshpande, 2014).

Currently, many companies in Indonesia are already utilizing information technology. Pascareno and Hermana (2015) evaluated the website of insurance companies in Indonesia and found that the top ten worldranked websites of insurance companies in Indonesia are Allianz Indonesia, Prudential Life Assurance, China Taiping Insurance, ACE Assurance, Astra Insurance, Manulife Indonesia, Great Eastern Life, Commonwealth Life, Adira Dinamika, and Zurich Insurance Indonesia. Hermana and Loho (2013) stated that the use of official websites as a medium of information and publication of financial statements still needs to be increased in life insurance companies in Indonesia.

The impact of digital transformation is manifest in the use of information technology in the field of insurance. Eling and Lehmann (2017) analyzed the impact of digitization on the insurance industry and found that the impact of the digitization on the insurance industry will affect the areas of marketing, product development, sales, underwriting, contract administration and customer service, claims management, and asset and risk management. Kusdani (2014) also analyzed the influence of perceptual factors on consumer attitudes and interests, in this case insurance customers, to use internet services. Garven (2002) stated that the internet will enhance insurance affordability and availability.

The rapid development of information technology in the insurance sector is the background of this research. The object of study is the official website managed by each general insurance company that markets motor vehicle insurance. The research asks whether the website allows the direct purchase of motor vehicle insurance products. Secondary questions are: Is the website of the insurance company that sells motor vehicle insurance in Indonesia rich with information and documents? What is the level of popularity of websites that already offer online motor vehicle insurance sales?

\section{Literature Review}

Based on Law No.40 of 2014 on Insurance, insurance is an agreement between two parties, namely, insurance companies and policyholders, and is the basis for premium revenue by insurance companies in return for:

a. providing reimbursement to the insured or the policyholder for any loss, damage, expense arising, loss of profits, or liability to any third party that the insured may suffer or the policyholder due to the occurrence of an uncertain event; or

b. providing payments based on the death of the insured or payments based on the life of the insured with the benefits of which the amount has been determined and based on the results of the fund manager.

The above definition implies two types of insurance: general insurance and life insurance. Ayat (2012) stated that in general insurance there are 13 types of insurance products commonly on the market with one being motor vehicle insurance. With motor vehicle insurance, the owner of the vehicle agrees to the insurer to make the annual premium payment. The company is also obliged to provide assurance to the insured vehicle in case of damage repair light to heavy and partial or complete replacement of motor vehicles insured if subjected to various damages caused by various matters in accordance with the agreement in the insurance.

There are generally two types of motor vehicle insurance coverage:

1. Total Loss Only (TLO)

TLO insurance only covers the risk of loss or damage to a vehicle that has been damaged beyond $75 \%$ and cannot be used again. The insurance company will pay a certain amount of money if such claim is accepted; however, it will not bear the cost of any damage (e.g., side windows or abrasions to the vehicle's surface) that does not exceed $75 \%$ (i.e., total loss). Because the protection provided is limited to only the total loss of the vehicle, this insurance product has a low premium.

2. All Risk 
All Risk insurance is a type of motor vehicle insurance that covers the risk of loss and damage to a motor vehicle regardless the magnitude or percentage of loss or damage. The insurance company will protect the partial or total loss of the car due to falling objects, fire, misconduct, theft, looting, collision, collision, or other traffic accidents. This type of insurance is also accompanied by extension guarantees, such as destruction caused by flood or damage caused by trapped in riot cases, as well as loss of vehicles and insurance protection for passenger vehicles. In addition to assuming all the risks on the vehicle, this type of insurance also protects if the motor vehicle were to crash into another vehicle, which is commonly referred to as "third-party liability." This type of insurance carries a higher premium than the TLO policy.

Table 1 lists the differences between TLO and All Risk motor vehicle insurance.

Table 1 Comparison of TLO and All-Risk Motor Vehicle Insurance

\begin{tabular}{cccc}
\hline No. & Comparison & Total Loss Only & All Risk \\
\hline 1 & Premium & Low & High \\
2 & Coverage & $\begin{array}{l}\text { Loss or damage to at least } 75 \% \\
\text { of the vehicle. }\end{array}$ & $\begin{array}{l}\text { Loss or damage regardless the } \\
\text { magnitude or extent. }\end{array}$ \\
\hline
\end{tabular}

\subsection{The role of the internet in the insurance industry}

Currently, the world is entering the era of digitalization, including in Indonesia. Utomo, Reimondos, Utomo, McDonald, and Hull (2013) found that $85 \%$ of people that live around Jakarta are smartphone users. As a result, internet access has become a daily requirement for most people. The internet has revolutionized the way business is conducted in all business fields, including the insurance industry. Tudor and Badea (2017) explained that information technology will play an important role in the insurance industry. However, Grossman, McCarthy, and Aronson (2004) found that while other financial institutions have been fast in implementing the internet to achieve sustainable competitive advantage, insurance companies have been slow to adopt ecommerce. However, some insurance companies have begun to use the internet as an alternative distribution channel, which is now a consumer expectation.

The potential benefits that the internet offers as a marketing platform are believed to greater than traditional marketing methods. Importantly, the costs of using electronic communication, e.g., the internet, are substantially lower compared with traditional face-to-face and printed communication. Consumers can find the products and prices of insurance products via the internet in their own time. Moreover, consumers can also obtain product information from other similar insurance companies in order to compare policies and prices, which encourages competition in the market.

According Sekulovska (2012), insurance companies can offer their products online through their corporate website. Web page: Almost all insurance companies have a web page to explain information related to the company and the products offered. This page supports the corporate marketing section similar to online brochures. There is no interaction between the client and the company and the company still uses the traditional sales channel.

Web portal: a portal is a collection of links to different webpages containing different information, but there is no consumer interaction. Some companies provide email media to communicate with clients but do not provide online applications to purchase insurance products.

Point-of-sale portal: a portal that sells certain goods and then offers insurance products for additional protection. For example, car dealers offer car insurance.

Intermediate brokers: brokers that represent and sell insurance products.

Reverse auction: In this model, clients are usually organizations that require group insurance. Clients announce their needs and then choose from the offers of several insurance companies.

Aggregators: Aggregators are sites that contain general information about insurance services. Aggregator approaches the concept of e-insurance and is accepted by almost all insurance companies.

\section{Methodology}

The object of this study is a collection of 74 official websites of conventional general insurance companies in Indonesia registered in the Financial Services Authority (OJK) as of March 2018. An "official website" is one that uses its domain and is managed by the general insurance company. Observational data were collected between May $7^{\text {th }}$ and May $14^{\text {th }}, 2018$. Observations were made on the website content, scope of information, popularity of the website, and daily unique visitors. This research is descriptive in nature in order to determine 
the initial level of website utilization for general insurance companies in Indonesia that market motor vehicle insurance.

The steps taken in the research process are as follows:

1. Check the official websites of 74 general insurance companies in Indonesia.

2. Check for accessibility of any motor vehicle insurance products on each website.

3. Check for an online application to buy motor vehicle insurance products.

4. Check website ranking of those websites that provide online applications to purchase motor vehicle insurance products using www.siteprice.com.

5. Check the number of unique visitors that visit websites that provide online applications to purchase motor vehicle insurance products using www.siteprice.com.

Siteprice.org is an appraiser of websites and lists website features such as the age of the website, number of unique visitors per day, Alexa rank, pages visited, number of backlinks, Google index, and others. In this study, the measurements taken are the number of unique visitors per day and Alexa rank. In this study, motor vehicle insurance products are not differentiated by type of insurance; i.e., "motor vehicle insurance products" includes both TLO and All Risk policies.

\section{Discussion and Results}

In Indonesia, there are currently 151 insurance companies, including conventional and sharia companies. Table 2 reports the number of insurance firms in Indonesia based on data from the Financial Services Authority as of March 2018. In Table 2, insurance companies are divided into five categories: life, general, social, reinsurance, and mandatory. The object of this research is conventional general insurance; thus, the focus of this study is the group of 74 conventional general companies based on OJK data as of March 2018.

Table 2 Insurance Companies in Indonesia

\begin{tabular}{lrrrr}
\hline & \multicolumn{2}{c}{ March 2018 } & & \\
\cline { 2 - 3 } Component & Conventional & Sharia* & & \\
\hline Insurance & 138 & 13 & 151 \\
Life insurance & 53 & 7 & 60 \\
General insurance & 74 & 5 & 79 \\
Reinsurance & 6 & 1 & 7 \\
Mandatory insurance & 3 & - & 3 \\
Social insurance (BPJS) & 2 & - & 2 \\
\hline
\end{tabular}

Of the 74 conventional general insurance companies listed with the OJK, 61 companies could be located and accessed through their official corporate website. Corporate websites for 13 companies could not be located and, thus, were removed from the study. Because each company is different, not all of the 61 companies have motor vehicle insurance products. Among the 61 companies, 53 general insurance companies offer motor vehicle insurance products. Those companies' websites provide enough information in explaining their products. In general, motor vehicle insurance products include both types of coverage (TLO and All Risk). Each company's website also explains the company's claims and network procedures in Indonesia. Of course, this information is expected to make it easier for customers when filing claims. Some companies provide downloadable forms, but these are generally only a claim submission form.

The information on these companies' websites is mostly about making a claim. Not many companies offer direct sales of insurance products through their website. Of the 53 insurance companies, only nine are general insurance companies with motor vehicle products offering online sales applications. In other words, only about $12 \%$ of total general insurance companies listed on the OJK offer online vehicle insurance applications. Table 4 is a list of insurance companies offering online sales for market motor vehicle insurance products. The online sales application of motor vehicle insurance products is similar to selling directly through an agent or coming to an office. In the online sales process, prospective customers are required to complete and then submit a form containing personal data and information on the vehicle to be insured. The company will then consider accepting or rejecting the submission based on the underwriter's appraisal. Usually, the company's website provides a simulation page before entering the online sales page. This allows prospective customers to simulate the cost of the vehicle they wish to insure. 
Table 3 Companies in Indonesia that Offer Online Motor Vehicle Insurance Sales

\begin{tabular}{ll}
\hline No. & Company \\
\hline 1 & PT Asuransi Sinar Mas \\
2 & PT Mandiri AXA General Insurance \\
3 & PT Asuransi Central Asia \\
4 & PT Asuransi Adira Dinamika \\
5 & PT Asuransi Umum Bumiputera Muda \\
& 1967 \\
6 & PT Fairfax Insurance Indonesia \\
7 & PT Bosowa Asuransi \\
8 & PT Asuransi Cakrawala Proteksi \\
9 & Indonesia \\
\hline
\end{tabular}

The performance of the nine websites with online sales was ranked according to siteprice.com. The ranking considers features such as the age of the website, number of unique visitors every day, rank in Alexa, pages visited, number of backlinks, Google index and others. However, this research focuses only on two indicators: the Alexa rank and unique daily visitors.

Alexa is a site that provides information about the ranking of a website. The smaller the Alexa rank the better its ranking position. The advantage is that better Alexa rankings will also attract advertisers to use the company's website. Table 5 describes the websites' performance based on siteprice.com. Alexa rank rankings for nine conventional general insurance companies marketing automobile insurance products online. PT Mandiri AXA General Insurance has the smallest Alexa rank $(285,016)$ and PT Asuransi Buana Independent has the highest (12,374,711). In addition to PT Mandiri AXA General Insurance, two other companies have low Alexa rankings: PT Asuransi Sinar Mas $(600,022)$ and PT Asuransi Central Asia $(1,571,063)$. High Alexa ratings are found for PT Mandiri. AXA General Insurance shows a higher level of website popularity compared with the other eight insurance companies that have online applications.

Table 4 Website Performance

\begin{tabular}{llll}
\hline No & Company & Alexa rank & $\begin{array}{l}\text { Daily } \\
\text { Unique } \\
\text { Visitors }\end{array}$ \\
\hline 1 & PT Mandiri AXA General Insurance & 285,016 & 930 \\
2 & PT Asuransi Sinar Mas & 600,022 & 1,250 \\
3 & PT Asuransi Central Asia & $1,571,063$ & 100 \\
4 & PT Asuransi Adira Dinamika & $2,524,129$ & 55 \\
5 & PT Asuransi Umum Bumiputera Muda & $3,469,618$ & 35 \\
& 1967 & $3,704,689$ & 25 \\
7 & PT Fairfax Insurance Indonesia & $6,051,818$ & 10 \\
8 & PT Bosowa Asuransi & $7,773,011$ & 10 \\
9 & PT Asuransi Cakrawala Proteksi & $12,374,711$ & 5 \\
\hline
\end{tabular}

The number of unique visitors in one day is an important measure because it illustrates how often the company's website is accessed by different people. The number of unique visitors entering the company's website the more likely the visitor will open the company's online product sales application and the greater the possibility of these visitors buying online. Table 5 ranks the number of unique visitors in a day for the nine websites under study. PT Asuransi Sinar Mas has the most unique visitors per day $(1,250)$ and PT Asuransi Buana Independent has the least (5). On average, the nine websites of general insurance companies that have online applications for motor vehicle insurance products only get 269 unique visitors per day.

Table 5 shows that the number of unique visitors per day visiting conventional general insurance company websites that market motor vehicle insurance products online is still small. These conditions indicate that the 
public cannot rely on the company's website to obtain information or services for insurance products. Nevertheless, there is still a chance the company gets new customers. Currently, the number of new customers who buy online is still small compared with those who buy through an agent or office; however, with the growth of information technology and ease of transactions, it is likely that the number of new online customers will increase.

\section{Conclusion}

The general insurance business is a risk-based entity that provides reimbursement to the insured or the policyholder due to loss, damage, expense incurred, loss of profit, or legal liability to a possible third party. Motor vehicle insurance is the best known general insurance product and policy numbers for vehicles rise along with the number of motor vehicles.

Information technology has expanded into all areas of business, including in the insurance industry, which has enabled companies to market and sell their products. The potential benefits of marketing motor vehicle insurance products online are believed to be greater than with traditional marketing methods.

In Indonesia, there are currently 74 conventional general insurance companies listed on the OJK. Of these, 61 can be located and accessed through their website. Of those, only 53 general insurance companies have motor vehicle insurance products and only nine have online applications for purchasing motor vehicle insurance products. This indicates that the utilization of the official websites of most general insurance companies is suboptimal. Apart from a few insurance companies that have an online application of product purchases, a high Alex rank and low number of unique visitors per day indicate low website popularity. The next performance is still the least number of unique visitors a day visiting the company's website. However, with the growth of information technology and ease of transactions, it is likely that the number of new online customers will increase.

\section{References}

Ayat, S. (2012). Pengantar Asuransi. STMA Trisakti. Jakarta.

Deshpande, N., Ahmed, S., \& Khode, A. (2014). Web Based Targeted Advertising: A Study Based on Patent Information. Procedia Economics and Finance, 11, 522-535.

Eling, M., \& Lehmann, M. (2017). The Impact of Digitalization on the Insurance Value Chain and the Insurability of Risks. The Geneva Papers on Risk and Insurance-Issues and Practice. Garven, J. R. (2002). On the Implication of the Internet for Insurance Market and Institution. Risk Management and Insurance Review, 5, 105-112.

Grossman, M., McCarthy, R. V., \& Aronson, J. E. (2004). E-Commerce Adoption in the Insurance Industry. Management Faculty Publications. Paper 30.

Available at: http://vc.bridgew.edu/management_fac/30

https://www.bps.go.id/linkTableDinamis/view/id/1133 accessed on 8 May 2018.

https://www.ojk.go.id/id/kanal/iknb/data-dan-statistik/asuransi/Default.aspx_accessed on 8 May 2018 .

Hermana, B., \& Loho, R. (2013). Transparansi Informasi Keuangan dan Popularitas Website Perusahaan Asuransi Jiwa di Indonesia. Jurnal Asuransi dan Manajemen Risiko, 1.

Klapkiv, L., \& Kalpkiv, J. (2017). Technological innovations in the insurance industry. Journal of Insurance, Financial Markets and Consumer Protection, 26, 67-78.

Kusdani, D. (2014). Persepsi terhadap Sikap dan Minat Pengguna Layanan Internet pada Perusahaan Jasa Asuransi. Jurnal Organisasi dan Manajemen, 10, 97-112.

Pascareno, B. E., \& Hermana, B. (1970). Evaluating Internet Based Financial Reporting Index on the Website of Indonesian Insurance Company. Journal of Internet Banking and Commerce, 20, 1-14.

Sekulovska, M. (2012). Internet Business Models for e-Insurance and Conditions in Republic of Macedonia. Procedia - Social and Behavioral Sciences, 44, 163-168.

Stroe, M. A. (2014). Insurances and consumer perception in the the Romanian insurance market. Procedia Economics and Finance, 15, 1717-1723.

Tudor, R., \& Badea, D. (2017). Operational risk quantification and modelling within Romanian insurance industry. In Proceedings of the International Conference on Business Excellence (Vol. 11, No. 1, pp. 637-648). DOI: $10.1515 /$ picbe-2017-0068, pp. 637-64.

Utomo, A., Reimondos, A., Utomo, I., McDonald, P., \& Hull, T. (2013). Digital Inequalities and Young Adults in Greater Jakarta: A Socio-Demographic Perspective. International Journal of Indonesian Studies, 1. 